\title{
PERAN GURU DALAM MEMBANGKITKAN MOTIVASI BELAJAR SISWA SERTA MEMBUATNYA MENJADI AKTIF DAN KREATIF DI DALAM KELAS
}

\author{
Julkifli,M.Pd \\ Dosen STKIP Budidaya
}

\begin{abstract}
ABSTRAK
Guru bertindak sebagai aktor, pembimbing, pengayom, serta patner di dalam kelas. Guru tidak hanya dituntuk untuk dapat mengelola pembelajaran dengan baik, akan tetapi juga harus bisa memaksimalkan potensi setiap siswanya. Memaksimalkan potensi siswanya dengan mengetahui minat dan keinginan siswanya, baik secara individual, maupun juga kelompok, serta mampu memberikan dorongan (motivasi) untuk menstimulasi peserta didik agar lebih giat, aktif, dan menjadi kreatif ketika proses belajar-mengajar sedang berlangsung. Pemberian motivasi untuk menjadikan kebiasaan yang positif pada diri siswa. Dengan adanya motivasi yang berasal dari guru (eksternal) maupun motivasi yang timbul dari diri siswa sendiri, diharapkan siswa menjadi lebih aktif, dan kreatif dalam proses belajar-mengajar di dalam kelas. Guru juga diperbolehkan menggunakan strategi pemberian reward (hadiah) kepada siswa berprestasi. Selain memberikan reward (hadiah) kepada siswa berprestasi, guru juga diperkenankan untuk memakai strategi punishment tentunya strategi ini adalah opsi kedua setelah pemakaian strategi reward. Dalam proses belajar-mengajar juga guru diharapkan mampu mengoptimalkan proses penyampaian inforrmasi dengan menggunakan media pembelajaran. Media pembelajaran adalah instrumen yang dipakai guru untuk memudahkan proses belajar-mengajar dan menjadikannya lebih menarik.
\end{abstract}

Kata kunci : minat, motivasi belajar, media pembelajaran.

\section{PENDAHULUAN}

Seorang guru memiliki tanggung jawab
yang besar dalam menyampaikan
pembelajaran dengan sebaik mungkin agar
peserta didiknya memahami pengetahuan
dengan sebaik mungkin. Akan tetapi dalam
menyampaikan pelajaran, sering kali ditemui
beberapa peserta didik yang cenderung kurang
tertarik (tidak antusias) dalam mengikuti
pembelajaran. Tentunya ada beberapa faktor
yang mempengaruhi hal ini,

Seorang guru memiliki tanggung jawab yang besar dalam menyampaikan permbelajaran dengan sebaik mungkin agar peserta didiknya memahami pengetahuan dengan sebaik mungkin. Akan tetapi dalam menyampaikan pelajaran, sering kali ditemui beberapa peserta didik yang cenderung kurang tertarik (tidak antusias) dalam mengikuti yang mempengaruhi hal ini, 
pembelajaran yang dilakukan oleh guru sebagai pengajar. Untuk itu Guru sebagai pengajar juga harus menciptakan suasana yang santai, riang, tenang, dan menyenangkan agar mahasiswa mengikuti penyampaian mata kuliah dengan santai dan bergairah. Untuk itu perlu diadakan interaksi yang baik tentunya dengan interaksi timbal balik antara guru dan siswanya, agar menstimulasi keaktifan siswa dalam mengikuti pelajaran yang sedang dilangsungkan. Fungsi guru sebagai pengajar, pembimbing, pendidik, pengayom, maka diperlukan berbagai peranan dari guru dosen untuk senantiasa membimbing serta memantau pola dan tingkah laku siswanya dalam interaksi yang mereka lakukan. Sardiman (2010) mengatakan bahwa, sebagian besar waktu yang dimiliki seorang guru banyak dipakai untuk kegiatan belajar- mengajar dan berinteraksi bersama siswanya.

Beberapa peranan guru menurut beberapa ahli pendidikan antara lain : (1) james j brown, mengemukakan bahwa tugas dan peranan guru antara lain, menguasai dan mengembangkan materi pembelajaran, merencanakan materi pembelajaran, mempersiapkan pelajaran sehari-hari, mengontrol dan mengevaluasi kegiatan Siswa; (2) havighurst, menjelaskan bahwa peranan guru di kelas sebagai employe (karyawan) dalam hubungan kedinasan, sebagai bawahan (subordinate) terhadap atasannya, sebagai kolega dalam hubungannya dengan anak didik, sebagai pengatur disiplin, evaluator dan pengganti dari orang tua; (3) katz, menggambarkan peranan dosen sebagai komunikator, sahabat yang dapat memberikan nasihat-nasihat, motivator, sebagai pemberi inpirasi dan dorongan, pembimbing

dalam pengembangan sikap dan tingkah laku dan nilai-nilai, dan orang yang menguasai bahan yang diajarkan.Oleh sebab itu, guru memiliki peranan yang sangat penting dalam upaya menggiring siswa menjadi aktif dan juga kreatif di dalam kelas, dikarenakan hubungan emosional antara guru dan siswa sangatlah dekat. Hubungan emosional antara guru dan siswa merupakan faktor yang sangat menentukan untuk keberhasilan transformasi pengetahuan yang dilakukan di dalam kelas. Hubungan ini juga haruslah harmonis, karena terciptanya hubungan yang harmonis akan melahirkan hal-hal yang positif yang berimplikasi terhadap sesuatu yang diinginkan (orientasi) antara guru sebagai pengajar (transformer pengetahuan) dan siswa. Mengacu pada latar belakang dan pemikiran tersebut, maka peran guru dalam mengaktifkan dan membuat siswa kreatif

akan dibahas dijabarkan guna untuk memahami dan mengetahui cara dan teknik membuat Siswa aktif dan kreatif di dalam kelas.

\section{PEMBAHASAN}

Dalam menciptakan kegiatan belajar yang baik, guru haruslah memiliki sikap yang professional, serta memiliki empat kompetensi yang dibutuhkan untuk menjadi seorang yang professional dalam mengajar. Keempat kompetensi itu antara lain : (1) pedagogik. yaitu kemampuan pemahaman terhadap Siswa, perancangan dan pelaksanaan pembelajaran, evaluasi hasil belajar, dan pengembangan Siswa untuk mengaktualisasikan berbagai potensi yang dimilikinya, (2) kompetensi kepribadian. yaitu, kemampuan personal yang mencerminkan kepribadian yang mantap, stabil, dewasa, arif dan berwibawa, menjadi teladan bagi Siswa, dan berakhlak mulia, (3) kompetensi sosial. yaitu, kemampuan guru untuk berkomunikasi dan bergaul secara efektif dengan Siswa, tenaga kependidikan, orang tua/wali Siswa, dan masyarakat sekitar., (4) professional. Yaitu, penguasaan materi pembelajaran secara luas dan mendalam, yang mencakup penguasaan materi 
kurikulum mata pelajaran di sekolah dan substansi keilmuan yang menaungi materinya, serta penguasaan terhadap struktur dan metodologi keilmuannya. Setelah memiliki empat kompetensi wajib bagi seorang pengajar, barulah guru bisa merumuskan tentang rencana dalam pembelajaran untuk membuat siswa aktif dan juga kreatif di dalam kelas. Segala keaktifan siswa dalam belajar sangat menentukan bagi keberhasilan percapaian tujuan pembelajaran. Oleh sebab itu, dosen sebagai pembimbing dan pengarah siswa juga berusaha dan berupaya untuk meminimalisir segala gangguan baik dari dalam diri mahasiswa tersebut (internal), maupun gangguan yang berasal dari luar (eksternal). Upaya meminimalir gangguan ini merupakan usaha untuk membuat siswa fokus dan konsentrasi ketikan pembelajaran berlangsung, sehingga guru bisa dengan mudah memberikan motivasi untuk siswa agar aktif dan kreatif dalam pembelajaran. Perlu diketahui bahwa dalam proses pembelajaran siswa merupakan subjek dari pembelajaran. Oleh sebab itu, dosen sebagai pembimbing dan pengarah hendaknya mampu memahami hal ini untuk dapat mengarahkan mahasiswa ke orientasi (tujuan) pembelajaran.

Guru hendaknya menjadi patner siswa dalam semua kegiatan belajar-

mengajar dan ini adalah konsep yang lebih modern dan relevan di jaman yang serba digital saat ini. Dalam belajar mengajar klasik, guru bertindak sebagai pemberi informasi secara keseluruhan, disebabkan minimnya akses informasi waktu itu. Bahkan transmitter juga masih bersifat terbatas. Akan tetapi di era digital sekarang ini, dosen tidak lagi bertindak sepenuhnya sebagai pemberi informasi, akan tetapi lebih kepada pengarah, pembimbing siswa dalam mencari dan mengeksplor informasi. Ada beberapa metode untuk membuat siswa menjadi aktif dan kreatif di dalam kelas, antara lain :

\section{Meningkatkan Minat}

Sebelum kita mengetahui minat belajar maka kita harus mengetahui pengertian minat dan belajar. Kata minat secara etimologi berasal dari bahasa inggris " interest" yang berarti kesukaan, perhatian (kecenderungan hati pada sesuatu), keinginan. Jadi dalam proses belajar siswa harus mempunyai minat atau kesukaan untuk mengikuti kegiatan belajar yang berlangsung, karena dengan adanya minat akan mendorong siswa untuk menunjukan perhatian, aktivitasnya dan partisipasinya dalam mengikuti belajar yang berlangsung.Menurut Ahmadi (2009: 148) "Minat adalah sikap jiwa orang seorang termasuk ketiga fungsi jiwanya (kognisi, konasi, dan emosi), yang tertuju pada sesuatu dan dalam hubungan itu unsur perasaan yang kuat”. Menurut Slameto (2003:180), "minat adalah kecenderungan yang tetap untuk memperhatikan dan mengenang beberapa kegiatan". Sedangkan menurut Djaali (2008:

121) "minat adalah rasa lebih suka dan rasa ketertarikan pada suatu hal atau aktivitas, tanpa ada yang menyuruh". Sedangkan menurut Crow\&crow (dalam Djaali, 2008:

121) mengatakan bahwa "minat berhubungan dengan gaya gerak yang mendorong seseorang untuk menghadapi atau berurusan dengan orang, benda, kegiatan, pengalaman yang dirangsang oleh kegiatan itu sendiri". Dari beberapa pendapat para ahli diatas dapat disimpulkan bahwa pengertian minat adalah rasa ketertarikan, perhatian, keinginan lebih yang dimiliki seseorang terhadap suatu hal, tanpa ada dorongan. Pembelajaran yang efektif akan tercipta jika siswa memiliki minat dalam proses kegiatan belajarmengajar. 
Minat sangat besar pengaruhnya terhadap efektifitas pembelajaran karena peserta didik akan cenderung melakukan sesuatu secara maksimal jika sesuatu tersebut merupakan minat atau keinginannya.

Sebaliknya, tanpa adanya minat atau keinginan, seseorang akan melakukan sesuatu setengah hati atau tidak maksimal dalam melakukannya. Siswa yang memiliki minat yang besar dalam terhadap suatu pelajaran akan lebih aktif untuk mempelajarinya begitu juga dengan kebalikannya. Hamalik (2010) menyatakan bahwa pengajar perlu sekali mengenal minat atau keinginan peserta didiknya, karena ini menjadi modal awal bagi seorang pengajar untuk memilih bahan

pelajaran, merencanakan pengalamanpengalaman belajar, menuntun mereka kearah pengetahuan, dan untuk mendorong motivasi belajar peserta didik.

\section{Membangkitkan Motivasi}

Manusia melakukan sesuatu hal dalam menjalani kehidupannya karena alasan tertentu dan adanya pendorong. Kekuatan pendorong yang ada dalam diri orang untuk melakukan aktivitas-aktivitas tertentu untuk mencapai sesuatu tujuan, disebut motif. Segala sesuatu yang berkaitan dengan timbulnya atau berlangsungnya motif itu disebut motivasi. Kata motivasi berasal dari bahasa Inggris yaitu "motive/motivation" yang berarti mendorong/dorongan. Secara umum motivasi dapat diartikan suatu keadaan yang dialami individu, yang mendorong individu itu untuk melakukan sesuatu ke arah pencapaian tujuan tertentu. Motif dalam psikologi berarti rangsangan, dorongan atau pembangkit tenaga bagi terjadinya suatu tingkah laku.

Motivasi sebagai keadaan dalam pribadi seseorang untuk mendorong keinginan individu untuk melakukan kegiatan tertentu guna mencapai suatu tujuan. Jadi motivasi yang ada pada seseorang akan mewujudkan suatu perilaku yang diarahkan pada tujuan mencapai sasaran kepuasan (Ranupandojo, 2000 : 78).

Purwanto (1990 : 61) menyatakan bahwa, "Motivasi atau dorongan adalah suatu pernyataan yang kompleks di dalam individu (siswa) yang mengarahkan tingkah laku terhadap suatu tujuan. Motivasi akan dirancang karena adanya tujuan. Motivasi dalam hal ini merupakan suatu aksi yaitu tujuan." Dalam hal ini motivasi juga tidak harus berasal dari satu arah (guru dan dosen). Akan tetapi motivasi juga bisa berasal dari dalam diri (internal). Oleh sebab itu munculnya motivasi bisa dipengaruhi oleh dua faktor, antara lain : (1) faktor internal (yang berasal dari diri sendiri), dan (2) faktor eksternal (yang berasal dari orang lain) dalam hal ini dosen dan guru. Syamsu Yusuf (2009: 23), menyebutkan faktor-faktor yang mempengaruhi motivasi belajar yaitu:

\section{Faktor Internal.}

a) Faktor Fisik

Faktor fisik meliputi nutrisi (gisi), kesehatan, dan fungsi-fungsi fisik (terutama panca indera).

b) Faktor Psikologis

Faktor psikologis berhubungan dengan aspekaspek yang mendorong atau menghambat aktivitas belajar pada siswa. 


\section{Faktor Eksternal.}

\section{a) Faktor Non-Sosial}

Faktor non-sosial meliputi keadaan udara (cuaca panas atau dingin), waktu (pagi, siang, malam), tempat (sepi, bising, atau kualitas sekolah tempat belajar), sarana dan prasarana atau fasilitas belajar.

\section{b) Faktor Sosial}

Faktor sosial adalah faktor manusia (guru, konselor, dan orang tua), baik yang hadir secara langsung maupun tidak langsung (foto atau suara). Proses belajar akan berlangsung dengan baik, apabila guru mengajar dengan cara menyenangkan, seprti bersikap ramah, memberi perhatian pada semua siswa, serta selalu membantu siswa yang mengalami kesulitan belajar. Pada 18 saat dirumah siswa tetap mendapat perhatian orang tua, baik material dengan menyediakan sarana dan prasarana belajar guna membantu dan mempermudah siswa belajar di rumah.

Oleh sebab pentingnya pemberian motivasi, baik itu dalam diri (internal), maupun dari luar (eksternal) maka ada beberapa cara untuk menumbuhkan motivasi belajar mahasiswa dan Siswa menurut Sardiman A. M (2007: 92-95), antara lain :

1) Memberi angka.

Umumnya setiap siswa ingin mengetahui hasil pekerjaannya, yakni berupa angka yang diberikan oleh guru. Siswa yang mendapat angkanya baik akan mendorong motivasi belajarnya menjadi lebih besar, sebaliknya siswa yang mendapat angka kurang, mungkin menimbulkan frustasi atau dapat juga menjadi pendorong agar belajar lebih baik. Dengan pemberian angka-angka yang baik untuk siswa, bisa menjadikan hal tersebut sebagai motivasi untuk siswa yang bersangkutan.

2) Hadiah.

Cara ini dapat dilakukan oleh guru dalam batas-batas tertentu misalnya pemberian hadiah kepada siswa yang mendapat atau menunjukan hasil belajar yang baik. Hadiah dapat dikatakan sebagai motivasi tetapi tidak selalu demikian, karena hadiah untuk suatu pekerjaan mungkin tidak akan menarik bagi seseorang yang tidak senang dan tidak berbakat untuk sesuatu pekerjaan tersebut, sehingga hadiah tidak selalu bisa menimbulkan motivasi.

3) Saingan/ kompetisi.

Saingan atau kompetisi dapat digunakan sebagai alat motivasi untuk mendorong belajar siswa. Hanya saja persaingan individual akan menimbulkan pengaruh yang tidak baik, seperti rusaknya hubungan persahabatan, perkelahian, pertentangan, persaingan antar kelompok belajar.

4) Ego-involvement.

Sebagai salah satu bentuk motivasi yang cukup penting karena menumbuhkan kesadaran kepada Siswa betapa pentingnya tugas-tugas dan menerimanya sebagai tantangan sehingga mereka bekerja keras 
dengan mempertaruhkan harga diri. Mereka akan berusaha dengan segenap tenaga untuk mencapai prestasi yang baik dengan menjaga harga dirinya, karena penyelesaian tugas dengan baik adalah simbol kebanggaan dan harga diri.

5) Memberi ulangan.

Siswa akan menjadi giat belajar apabila mengetahui akan ada ulangan. Maka, memberi ulangan adalah salah satu upaya sarana memotivasi siswa dalam belajar. Tetapi yang harus diingat adalah guru jangan terlalu sering memberikan ulangan karena dapat membuat siswa bosan karena terlalu sering dan bersifat rutinitas. Guru juga harus terbuka, maksudnya jika akan diadakan ulangan harus diberitahukan kepada siswanya.

6) Mengetahui hasil.

Dengan mengetahui hasil pekerjaan, apalagi jika mengalami kemajuan/ peningkatan, akan mendorong siswa untuk terus belajar dan lebih giat lagi.. semakin mengetahui bahwa hasil belajar selalu mengalami kemajuan, maka aka nada motivasi pada diri siswa untuk terus belajar, dengan suatu harapan hasilnya selalu meningkat.

7) Pujian.

Pemberian pujian kepada murid atas hal-hal yang telah dilakukan dengan berhasil besar manfaatnya sebagai pendorong belajar, dengan pemberian pujian akan menimbulkan rasa senang dan puas.

8) Hukuman.

Salah satu cara meningkatkan motivasi belajar siswa adalah dengan memberikan hukuman. Hukuman sebagai reinforcement yang negatif apabila diberikan secara tepat dan bijak bisa menjadi alat motivasi. Oleh karena itu, guru harus memahami prinsipprinsip pemberian hukuman.

9) Hasrat.

untuk belajar Adanya hasrat untuk belajar, berati ada unsur kesengajaan, ada maksud untuk belajar. Hasrat untuk belajar berati pada diri anak tersebut memang terdapat motivasi untuk belajar, sehingga sudah barang tentu hasilnya akan lebih baik.

10) Minat.

Motivasi erat hubungannya dengan minat. Motivasi muncul karena ada kebutuhan, begitu juga dengan minat sehingga tepatlah kalau minat merupakan alat motivasi yang pokok.

11) Tujuan yang diakui.Rumusan tujuan yang diakui dan diterima dengan baik oleh siswa merupakan alat motivasi yang sangat penting. Sebab dengan memahami tujuan yang harus dicapai, dirasa sangat berguna dan menguntungkan bagi siswa, maka akan timbul gairah untuk terus belajar. Dari uraian di atas dapat disimpulkan bahwa cara menumbuhkan motivasi belajar yaitu dengan memberi angka, hadiah, saingan/ kompetisi, ego-involvement, memberikan ulangan, mengetahui hasil pekerjaan, pujian, hukuman, hasrat untuk belajar, minat dan tujuan yang diakui. Menurut M.Sobry Sutikno (2007) ada beberapa strategi yang bisa diterapkan untuk menumbuhkan motivasi belajar Siswa antara lain :

a) Menjelaskan tujuan belajar.

Pada permulaan belajar-mengajar seharusnya terlebih dahulu seorang pengajar (dosen) menjelaskan mengenai tujuan instruksional khusus yang akan 
dicapainya kepada siswa. Makin jelas tujuan, maka akan semakin besar pula motivasi dalam belajar.

b) Hadiah.

Memberikan hadiah kepada Siswa yang berprestasi akan memacu semangat mereka untuk bisa belajar dengan lebih giat lagi. Di Samping itu, siswa yang belum berprestasi akan termotivasi untuk bisa mengejar siswa yang berprestasi.

c) Kompetisi/ saingan.

Hendaknya seorang pengajar (dosen) dan juga guru berusaha mengadakan persaingan diantara Siswanya untuk meningkatkan prestasi belajarnya dan berusaha memperbaiki hasil prestasi yang telah dicapai sebelumnya.

d) Memberikan pujian.

Sudah sepantasnya Siswa yang memiliki prestasi diberikan pujian ataupun reward (hadiah) atau juga penghargaan. Dengan pemberian reward ini, Siswa akan sangat merasa dihargai dan diperhatikan oleh pengajarnya (dosen dan guru)

e) Hukuman.

Selain hadiah maka pemberian hukuman juga bisa memacu motivasi Siswa. Akan tetapi ini adalah opsi yang tidak dianjurkan dan sebaiknya dilakukan setelah opsi pemberian reward, dan itupun ketika opsi pemberian reward tidak berjalan dengan efektif. Hukuman diberikan bukan untuk membuat Siswa trauma atau takut, akan tetapi untuk memotivasi Siswa agar merubah dirinya menjadi lebih baik.

f) Membangkitkan dorongan kepada Siswa untuk belajar dengan pemberian perhatian yang lebih kepada peserta didik.

g) Membentuk kebiasaan belajar yang baik.

h) Membantu kesulitan belajar Siswa secara individual maupun kelompok.

i) Menggunakan metode yang bervariasi

j) Menggunakan media yang baik yang relevan dengan tujuan dari pembelajaran.

\section{Menggunakan \\ Pembelajaran}

Media

media pembelajaran adalah semua alat (bantu) atau benda yang digunakan untuk kegiatan belajar mengajar, dengan maksud menyampaikan pesan (informasi) 
pembelajaran dari sumber (guru maupun sumber lain) kepada penerima (dalam hal ini anak didik atau warga belajar). Berdasarkan pendapat ahli tersebut dapat disimpulkan bahwa media pembelajaran alat bantu untuk menyampaikan pesan dari sumber kepada penerima, Latuheru (1988: 14).

$$
\text { Sardiman }
$$

menjelaskan media pembelajaran adalah segala sesuatu yang dapat digunakan untuk menyalurkan pesan dari pengirim ke penerima pesan. Dalam hal ini adalah proses merangsang pikiran, perasaan, perhatian, dan minat serta perhatian siswa sehingga proses belajar dapat terjalin. Berdasarkan pernyataan tersebut dapat disimpulkan bahwa media pembelajaran adalah alat bantu yang digunakan oleh guru sebagai alat bantu mengajar. Dalam interaksi pembelajaran, guru menyampaikan pesan ajaran berupa materi pembelajaran kepada siswa. Hamalik (dalam Arsyad, 2002: 15) mengemukakan bahwa pemakaian media pengajaran dalam proses belajar mengajar dapat membangkitkan keinginan dan minat yang baru, membangkitkan motivasi dan rangsangan kegiatan belajar, dan bahkan membawa pengaruh-pengaruh psikologis terhadap siswa. Penggunaan media pembelajaran pada tahap orientasi pembelajaran akan sangat membantu keefektifan proses pembalajaran dan penyampaian pesan dan isi pelajaran pada saat itu. Di samping membangkitkan motivasi dan minat siswa, media pembelajaran juga dapat membantu siswa menigkatkan pemahaman, menyajikan data dengan menarik dan terpercaya, memudahkan penafsiran data dan memadatkan informasi. Paparan fungsi media pengajaran Hamalik di atas menekankan bahwa penggunaan media pembelajaran dalam kegiatan belajar mengajar dapat meningkatkan motivasi dan keinginan belajar siswa serta siswa dapat tertarik dan lebih mudah memahami materi yang disampaikan. Brown (1983:17) menyatakan bahwa "educational media of all types incresaingly important roles in enabling students to reap benefits from individualized learning", semua jenis media pembelajaran akan terus meningkatkan peran untuk memungkinkan siswa memperoleh manfaat dari pembelajaran yang berbeda. Menggunakan media pembelajarn secara efektif, akan menciptakan suatu proses belajar mengajar yang optimal. Pernyataan tersebut dapat disimpulkan 
bahwa media pembelajaran merupakan salah satu bagian penting dari proses pembelajaran. Media pembelajaran memberikan manfaat dari pendidik maupun Siswa.

\section{Arsyad}

mengemukakan manfaat media media pengajaran dalam proses belajar mengajar sebagai berikut.

1. Media pengajaran dapat memperjelas penyajian pesan dan informasi sehingga dapat memperlancar dan meningkatkan proses dan hasil belajar.

2. Media pengajaran dapat meningkatkan dan mengarahkan perhatian anak sehingga dapat menimbulkan motivasi belajar, interaksi yang lebih langsung antara siswa dengan lingkungannya, dan memungkinkan siswa untuk belajar sendiri-sendiri sesuai dengan kemampuan dan minatnya.

3. Media pengajaran dapat mengatasi keterbatasan indera, ruang, dan waktu.

4. Media pengajaran dapat memberikan kesamaan pengalaman kepada siswa tentang peristiwa-peristiwa di lingkungan mereka, serta memungkinkan terjadinyya interaksi langsung dengan guru, masyarakat, dan lingkungan.

Pendapat Arsyad tentang manfaat media pembelajaran di atas dapat disimpulkan bahwa media pembelajaran dapat membantu proses belajar mengajar. Penyampaian pesan dan isi pelajaran dapat diterima baik oleh siswa. Menurut Latuheru (1988: 23) manfaat media pembelajaran yaitu:

1) media pembelajaran menarik dan memperbesar perhatian anak-anak didik terhadap materi pengajaran yang disajikan.

2) media pembelajaran mengurangi, bahkan dapat menghilangkan adanya verbalisme.

3) media pembelajaran mengatasi perbedaan pengalaman belajar berdasarkan latar belakang sosial ekonomi dari anak didik.

4) media pembelajaran membantu memberikan pengalaman belajar yang sulit diperoleh dengan cara yang lain.

5) media pembelajaran dapat mengatasi masalah batas-batas ruang dan waktu. 
6) media pembelajaran dapat membantu perkembangan pikiran anak didik secara teratur tentang hal yang mereka alami.

7) media pembelajaran dapat membantu anak didik dalam mengatasi hal yang sulit nampak dengan mata.

8) media pembelajaran dapat menumbuhkan kemampuan berusaha sendiri berdasarkan pengalaman dan kenyataan.

9) media pembelajaran dapat mengatasi hal/peristiwa/kejadian yang sulit diikuti oleh indera mata.

10) media pembelajaran memungkinkan terjadinya kontak langsung antara anak didik, guru, dengan masyarakat, maupun dengan lingkungan alam di sekitar mereka.

Paparan tentang manfaat media oleh Latuheru dapat disimpulkan bahwa media bermanfaat untuk mengatasi permasalan yang dialami guru dan siswa dalam pembelajaran. Berdasarkan penjelasan di atas, dapat dikatakan bahwa memanfaatkan media pembelajaran adalah membantu dalam penyampaian bahan pengajaran kepada siswa untuk meningkatkan kualitas siswa yang aktif dan interaktif sehingga dapat mendukung kelancaran kegiatan pembelajaran disekolah.

\section{PENUTUP}

Guru sebagai tenaga professional harus berupaya untuk menjadikan peserta didiknya aktif dan kreatif ketikan berlangsungnya pembelajaran di dalam kelas. Upaya untuk meningkatkan keaktifan dan memunculkan kreatifitas peserta didik adalah dengan mengetahui minat dan keinginan siswa dalam seluruh mata pelajaran yang diajarkan. Dengan mengetahui minat dan keinginan siswa, tentunya akan memudahkan guru dalam menentukan rencana, proses, serta tujuan dari pembelajaran itu sendiri. Selain itu guru juga harus berupaya untuk memotivasi siswa, sehingga siswa terbiasa termotivasi untuk selalu aktif dalam setiap pembelajaran. Stimulus motivasi diberikan terus menerus oleh guru untuk membiasakan siswa untuk bisa memunculkan motivasi secara internal (dalam diri) sekalipun guru juga membantu dengan memberikan motivasi (eksternal). Pemberian reward dan punishment juga memotivasi anak untuk berubah menjadi lebih baik dari sebelumnya. Guru juga dituntut untuk kreatif dalam menyampaikan pelajaran, tentunya dengan menggunakan media pembelajaran. Media merupakan instrumen yang dipakai guru dalam mengajar yang bertujuan untuk 
memudahkan proses belajar-mengajar. Dengan memperhatikan ketiga unsur ini diharapkan peserta didik akan menjadi aktif di dalam kelas. Keaktifan akan melahirkan kreatifitas, dan kreatifitas akan melahirkan sesuatu yang menyenangkan. Pembelajaran yang menyenangkan akan terjauh dari kata bosan serta lebih dekat dengan tercapainya tujuan dari pembelajaran tersebut.

\section{KEPUSTAKAAN}

Ahmadi, A. (1991). Teknik belajar yang efektif. Jakarta : Rineka Cipta.

Aritonang, Keke T. (2008). Minat dan Motivasi dalam Meningkatkan Hasil Belajar Siswa. Jurnal Pendidikan Penabur, 7(10): 11-21.

A.M, Sardiman. (2016). Interaksi dan Motivasi Belajar Mengajar. Jakarta : PT Raja Grafindo.

Azhar, Arsyad. (2010). Media Pembelajaran. Jakarta : PT. Raja Grafindo Persada.

Djamarah, Syaiful Bahri. (2011). Psikologi Belajar. Jakarta: Rineka Cipta.

Dimyati dan Mudjiono. (2006). Belajar dan Pembelajaran. Jakarta : Rineka Cipta.

Hamalik, Oemar. (2008). Proses Belajar Mengajar. Bandung : Bumi Aksara. 